\title{
EFNB2 Gene
}

National Cancer Institute

\section{Source}

National Cancer Institute. EFNB2 Gene. NCI Thesaurus. Code C105841.

This gene is involved in cell-cell signaling. 